\title{
Spectroscopic studies of nanometric Zinc Oxide
}

\section{N.M. Hamed , A.B.EL-Bialy, S.S. Hamed, S. Abd El-Mongy}

Faculty of Women for Art, Science and Education, physics department, Ain Shams University

\begin{abstract}
Zinc Oxide nanoparticles have been prepared by chemical precipitation method using Zinc nitrate. The effect of different parameters on particle size (growth temperature, concentration of $(\mathrm{NaOH})$ and time of stirring) were studied. The prepared $(\mathrm{ZnO})$ nanopowder was characterized by X-ray diffraction (XRD), Transmission Electron Microscope (TEM) and Fourier-transform Infrared Spectrometer (FT-IR). (XRD) patterns proved that (ZnO) nanoparticles had a hexagonal crystal structure and the particle size varied from (11.1-18.3) nm. (TEM) picture reveals the morphology and particle size of Zinc Oxide nanoparticles. The presence of defects and impurity contents in $(\mathrm{ZnO})$ nanoparticles were characterized by Fourier-transform infrared (FTIR) spectrometer.
\end{abstract}

Keywords: ZnO nanoparticle, XRD, FTIR, TEM

\section{Introduction}

The wurtzite zinc oxide $(\mathrm{ZnO})$ is a distinctive native n-type semiconductor (Kahouli et al., 2015). It is considered as one of the most promising and novel material because of its unique catalytic, electrical, electronic, optical and antimicrobial properties as well as its low cost and extensive applications in diverse areas (Solati et al., 2016). It has a wide band gap of (3.37 e.v) and high excitation binding energy of (60 mev) at room temperature (Gyu-Chul et al., 2005; Qiuxiang et al., 2007). The high excitation binding energy of ( $\mathrm{ZnO}$ ) would allow for excitonic transitions even at room temperature, which could mean high radiated recombination efficiency for spontaneous emission as well as a lower threshold voltage for laser emission(Koet al., 2003; Zaouk et al., 2006).

Zinc oxide $(\mathrm{ZnO})$ has an important role due to its unique morphology and their distinguished performance (Zhang et al., 2007) in electronics (Xu et al., 2004), optics (He et al., 2006), and photonics (Ma et al., 2006). ZnO displays a wide spectrum of applications, including gaseous sensors,fluorescent materials, photo catalysts, and additives in many industrial products, catalysts in ceramics, cosmetics and in the paint and rubber industries (Skapin et al., 2007).

*Corresponding author. E-mail: neveenmahmoud32@gmail.com 
In recent times, nanoparticles have been attracting great attention for their potential applications in many fields; therefore, nanotechnology becomes a rapidly developing branch of material science, which is the science of tiny and its properties caused by smallness. Nanotechnology is defined as to decrease the size of a material by size less than (100) nanometers (Keller et al., 2010). ZnO nanomaterial has been investigated for its important properties. Many methods have been described for the production of $\mathrm{ZnO}$ nanostructures such as laser ablation (Scarisoreanu et al., 2005), electrochemical deposition (Berber et al., 2005), sol-gel methods (Ristiæ et al., 2005), chemical vapor deposition (Wu et al., 2002), molecular beam epitaxial (Chen et al., 1998), common thermal evaporation method(Takahashi et al., 2000) and solid-vapor phase thermal sublimation technique. Many shapes shave been synthesized under specific growth conditions such as nanocombs, nanorings, nanohelixes, nanosprings, nanobelts, nanowires and nanocages of $\mathrm{ZnO}$ (Wang, 2004).

In the present work, synthesis of $\mathrm{ZnO}$ nanoparticles is reported using chemical method. The effect of different parameters (temperature, concentration of $\mathrm{NaOH}$ and time of stirring) on the particle size of the synthesis $\mathrm{ZnO}$ nanoparticles was studied. The characterization of $\mathrm{ZnO}$ nanoparticles was examined using X-ray diffraction and transmission electron microscopy (TEM), (FT-IR) spectroscopy.

\section{Experiment}

\subsection{Material and Sample Preparation}

The chemical precipitation method was used to fabricate $(\mathrm{ZnO})$ nanoparticles by using zinc nitrate $\left[\mathrm{Zn}\left(\mathrm{NO}_{3}\right)_{2} \cdot 6 \mathrm{H}_{2} \mathrm{O}\right]$ and sodium hydroxide $(\mathrm{NaOH})$. All salts were purchased from Al Gomhouria Company, Cairo, Egypt.

$\mathrm{ZnO}$ nanoparticles were prepared in a similar manner as described elsewhere (Nejati et al., 2011). A $0.2 \mathrm{M}$ solution of zinc nitrate and a $4.0 \mathrm{M}$ alkali solution of sodium hydroxide were prepared by dissolving zinc nitrate $\mathrm{Zn}\left(\mathrm{NO}_{3}\right)_{2} \cdot 6 \mathrm{H}_{2} \mathrm{O}$ and $\mathrm{NaOH}$, respectively, in deionized water. To prepare $\mathrm{ZnO}$ nanoparticles, $25 \mathrm{~mL}$ of the alkali solution (4.0 $\mathrm{M} \mathrm{NaOH})$ was dropped at an approximate rate of $5 \mathrm{~mL} / \mathrm{min}$ into a mother solution prepared by mixing $25 \mathrm{~mL}$ of $0.2 \mathrm{M} \mathrm{Zn}\left(\mathrm{NO}_{3}\right)_{2}$ solution and $50 \mathrm{~mL}$ of deionized water with stirring. The final $\mathrm{pH}$ of the mixture was fixed at 13 because highly basic conditions are conducive to the direct preparation of $\mathrm{ZnO}$ crystals (Equations 1-3) (Kawano et al., 2008)

$\mathrm{Zn}\left(\mathrm{NO}_{3}\right)_{2} \rightarrow \mathrm{Zn}^{+2}+2 \mathrm{NO}_{3}^{-}$

$\mathrm{Zn}^{+2}+2 \mathrm{OH}^{-} \rightarrow \mathrm{Zn}(\mathrm{OH})_{2}$

$\mathrm{Zn}(\mathrm{OH})_{2} \rightarrow \mathrm{ZnO}+\mathrm{H}_{2} \mathrm{O}$

On maintaining the mixture at $60^{\circ} \mathrm{C}$, precipitation occurred $2 \mathrm{~h}$ after mixing the solutions. The products obtained by centrifugation were washed with deionized water and then dried at $60^{\circ} \mathrm{C}$. 


\subsection{Techniques used}

The developed samples were studied by The Philips X'Pert 1 X-ray diffractometer (XRD) with $\mathrm{Cu}-\mathrm{K}_{\alpha}$ radiation. The morphology of the samples was observed by transmission electron microscope JEM-2100 EXII. ZnO nanoparticles were characterized by Nicolet 6700 Thermo Scientific IR Spectrometer with Mid IR (400-4000) $\mathrm{cm}^{-1}$, the samples were grinded with Kbr and formed a desk for FT-IR spectrometer.

\section{Result and discussion}

\subsection{Factors affecting the synthesis of $\mathrm{ZnO}$ nanoparticles}

For the development of an accurate synthesis $\mathrm{ZnO}$ nanoparticle, the influence of some factors such as temperature, concentration of $\mathrm{NaOH}$ and stirring time has to be studied.

\subsubsection{Effect of Temperature}

The temperature varied between 30 to $90{ }^{\circ} \mathrm{C}$ while keeping the rest of the experimental parameters fixed at appropriate values (concentration of $\mathrm{NaOH}$ at $4 \mathrm{~mol}$ and time stirring $2 \mathrm{~h}$ ). Fig. 1 illustrates the XRD pattern of $(\mathrm{ZnO})$ nanoparticles under the growth temperature. The diffraction peaks $(2 \theta)$ located at $32.140^{\circ}, 34.825^{\circ}, 36.649^{\circ}, 48.023^{\circ}, 57.118^{\circ}, 63.429^{\circ}$, $68.556^{\circ}$ and $69.660^{\circ}$ have been keenly indexed as hexagonal wurtzite phase of ZnO. The sharp diffraction peaks apparent in the figures indicate good crystallinity of the $\mathrm{ZnO}$ nanoparticles. The synthesized nanopowder was free of impurities as it does not contain any characteristics XRD peaks other than $\mathrm{ZnO}$ peaks. The average particle size of the prepared sample was calculated through measuring the full width at half maximum (FWHM) using Scherrer formula (Khoshhesab et al., 2011). The grain size was found to range from (11.1 to 18.3) $\mathrm{nm}$ depending on the growth temperatures. The particle size derived from the FWHM of the more intense peak corresponding to (101) planes located at $36.649^{\circ}$.

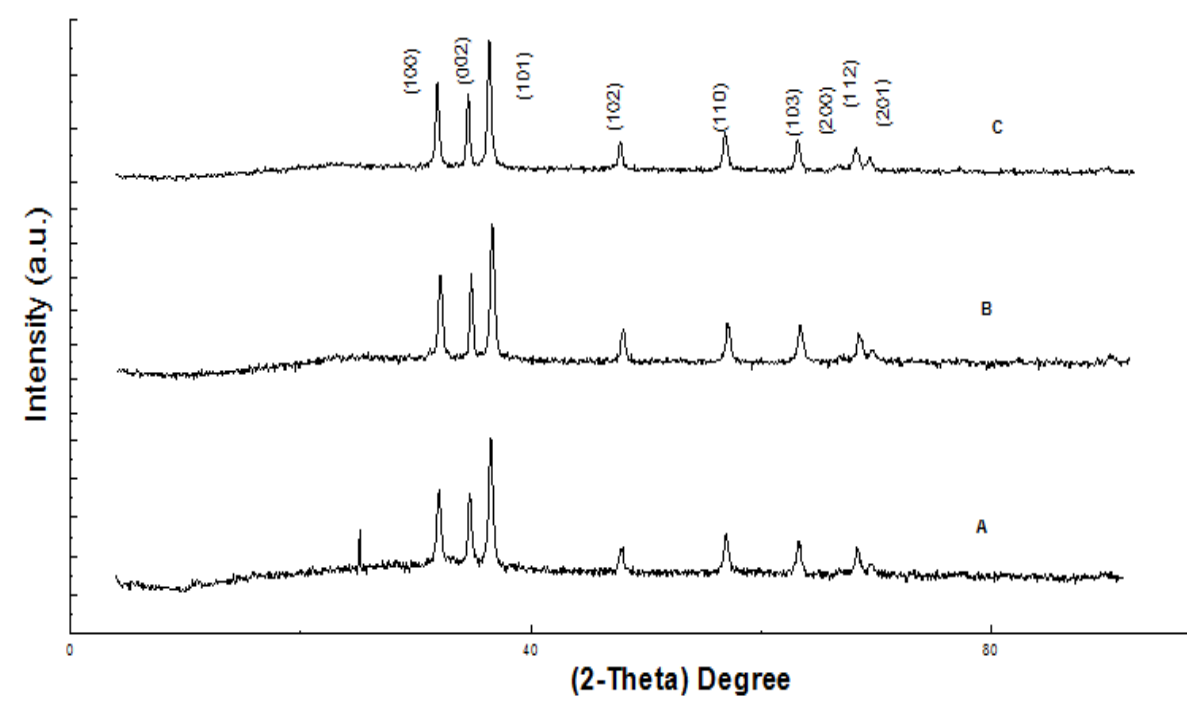

Fig. $1 \mathrm{XRD}$ pattern of $(\mathrm{ZnO})$ nanoparticles with changing the temperature (A) $30^{\circ} \mathrm{C}$, (B) $60^{\circ} \mathrm{C}$ (C) $90^{\circ} \mathrm{C}$

( $\mathrm{NaOH}$ concentration $4 \mathrm{~mol}$, stirring time $2 \mathrm{~h}$ ). 
Fig. 2 represents the relation between the grain size and (FWHM) of the highest diffraction peaks of $\mathrm{ZnO}$ nanoparticles with different temperatures. It is clear from this fig. that as the temp increases FWHM decreases and the grain size increases. This may be due to the change in different crystallographic planes (Aneesh et al., 2007).

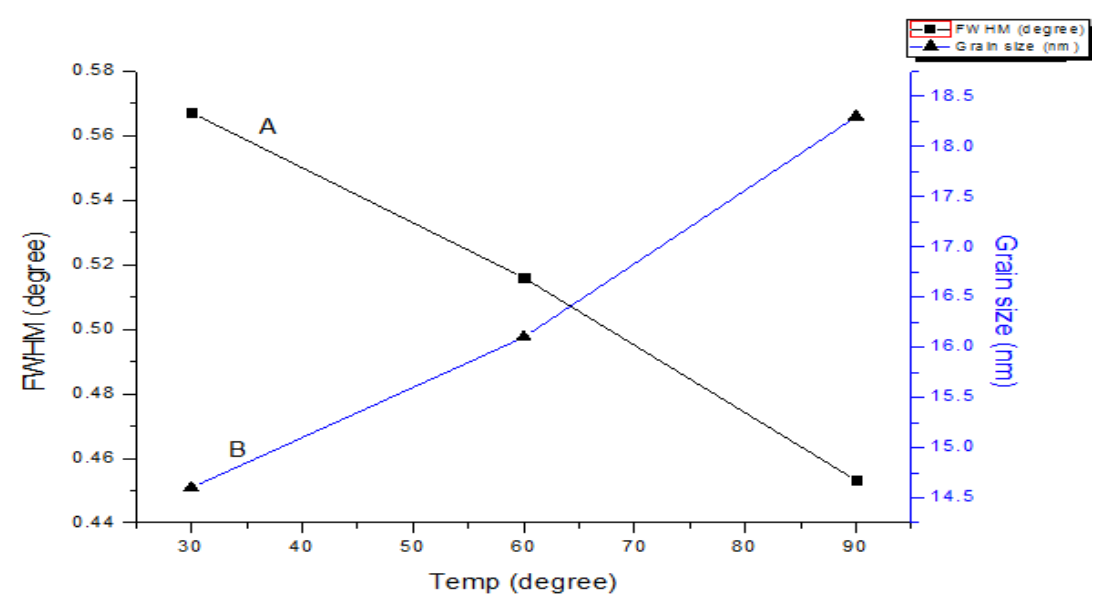

Fig. 2 The relation between (A) full width at half maximum and (B) the grain size of $\mathrm{ZnO}$ nanoparticles at different temperatures.

To confirm the formation of nanoparticle size for the prepared sample, the sample was studied by TEM. Fig. 3 shows (TEM) image of the $(\mathrm{ZnO})$ nanoparticles synthesized at temperature $30^{\circ} \mathrm{c}$, concentration of $\mathrm{NaOH} 4 \mathrm{~mol}$ and stirring time $2 \mathrm{~h}$. It can be noticed that, the products are composed of the particles with nearly spherical shape. It has an average size about $17.5 \mathrm{~nm}$ which confirms the particle size calculated from sherrer's equation. TEM micrographs show that some nanoparticles consist of a black core with gray shells. If the black cores are taken as the non-oxide $\mathrm{Zn}$ atoms and the gray shells indicate $\mathrm{ZnO}$, one can see that small nanoparticles are quite $\mathrm{ZnO}$ (E. Solati et al., 2016).

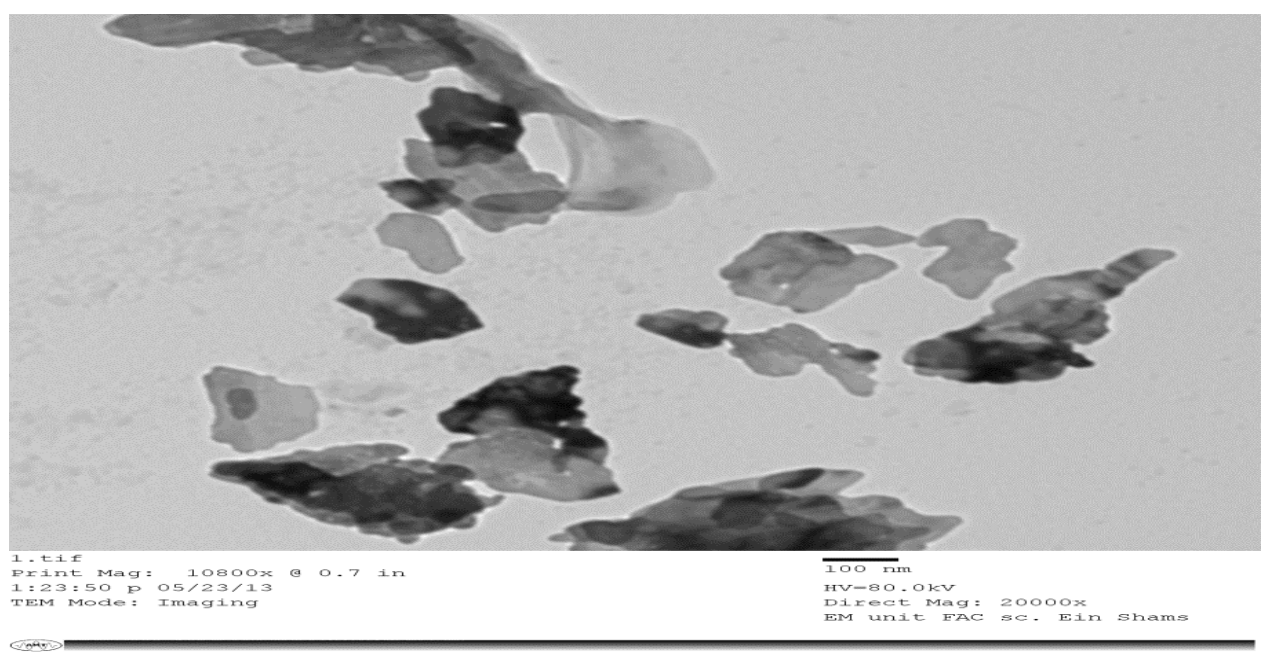

Fig. 3 Transmission Electron Microscope (TEM) of ( $\mathrm{ZnO})$ nanoparticle. 
The FT-IR spectra of samples of $\mathrm{ZnO}$ nanoparticles are generally influenced by the particle size and morphology (Ismail 1991). Fig. 4 shows the FT-IR spectra of synthesis ZnO nanoparticles under the variation of temperature. The peak at $564 \mathrm{~cm}^{-1}$ is related to the stretching vibrations of $\mathrm{Zn}-\mathrm{O}$ bonds. The peak at $3391 \mathrm{~cm}^{-1}$ indicates the presence of $\mathrm{OH}$ residue, probably due to atmosphere moisture (Becheri et al., 2008) at $30^{\circ} \mathrm{C}$. This peak is shifted to $3429 \mathrm{~cm}^{-1}$ at $60^{\circ} \mathrm{C}$ and disappeared at $90^{\circ} \mathrm{C}$. It should be noticed that the peak at (1504) $\mathrm{Cm}^{-1}$ may be attributed to the presence of bending of $\mathrm{OH}$ group of chemisorbed/physisorbed water molecules on $\mathrm{ZnO}$ surface which gradually disappear with increasing temperature (Radhika, et al., 2017). The best temp. which gives the best grain size of the synthesized $\mathrm{ZnO}$ nanoparticles was found to be at $30^{\circ} \mathrm{C}$.

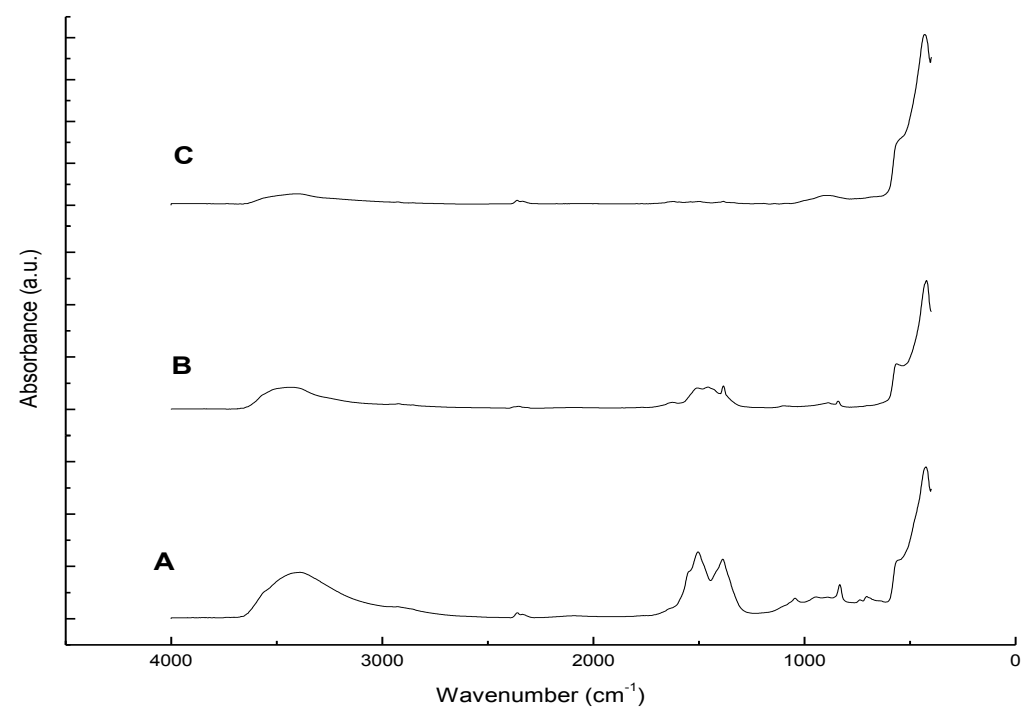

Fig. 4 FT-IR spectra of the synthesized $(\mathrm{ZnO})$ nanoparticle at various growth temp. (A, B, C) $(30,60,90){ }^{\circ} \mathrm{C}$ respectively,

$\mathrm{NaOH}$ concentration $4 \mathrm{~mol}$, time stirring $2 \mathrm{~h}$.

\subsubsection{Effect of $\mathrm{NaOH}$ Concentration}

The particle size of Zinc Oxide nanoparticles is also affected by changing of the concentration of $(\mathrm{NaOH})$. The concentration of $\mathrm{NaOH}$ varied from 2-5 mol while keeping the temperature at $30^{\circ} \mathrm{c}$ and time of stirring at $2 \mathrm{~h}$. Fig. 5 illustrates the XRD pattern of synthesized $(\mathrm{ZnO})$ nanoparticles. From this pattern, it can be seen that the (FWHM) of the (101) diffraction peak decreases by increasing the concentration of $(\mathrm{NaOH})$ and the grain size of synthesized ( $\mathrm{ZnO})$ nanoparticles increases (Aneesh et al., 2007) from $11.093 \mathrm{~nm}$ to 12.87 $\mathrm{nm}$. This relation is depicted in Fig. 6. 


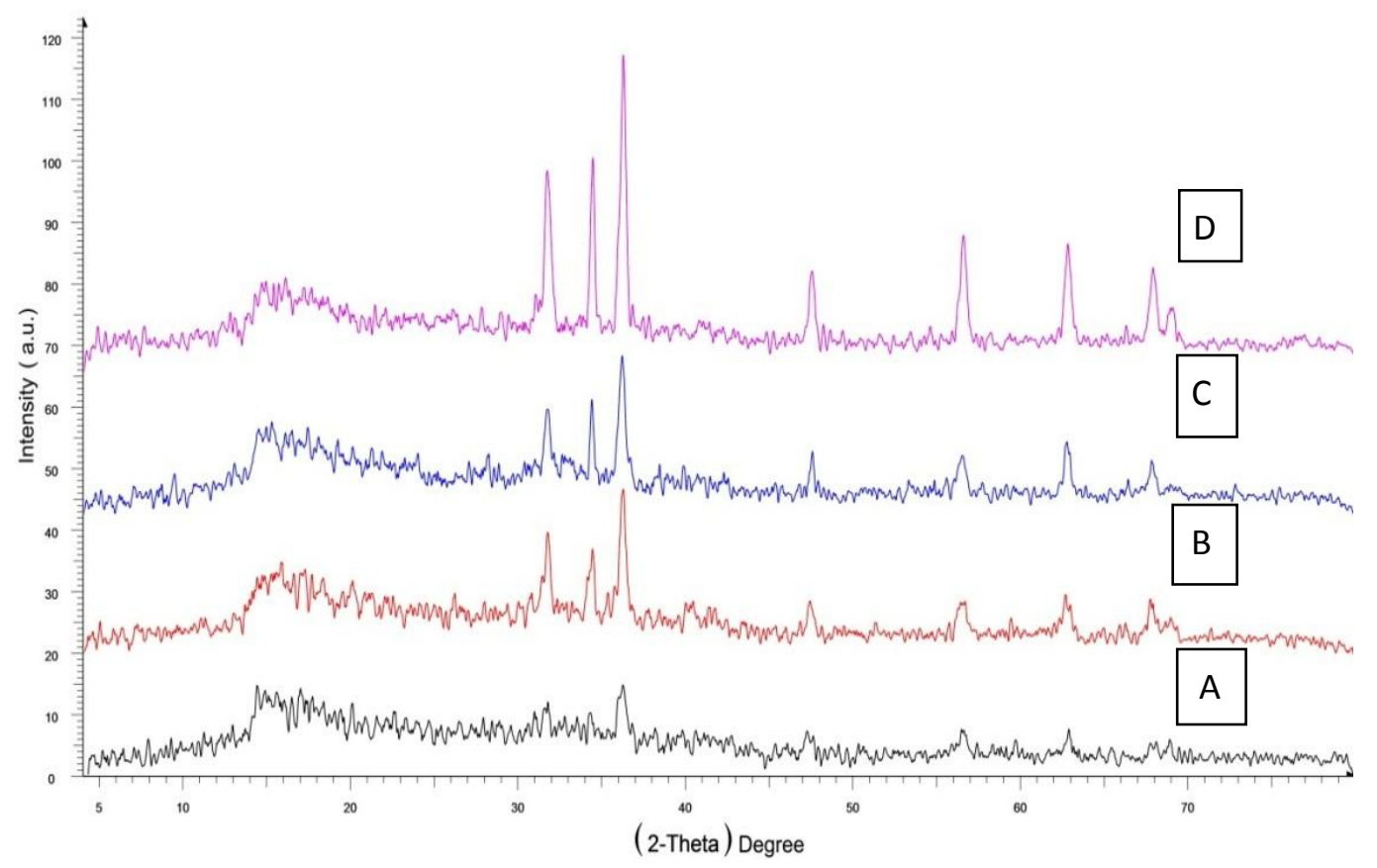

Fig. $5 \mathrm{XRD}$ pattern of $(\mathrm{ZnO})$ nanoparticles at temperature $30^{\circ} \mathrm{c}$, for 2 hours and at $(\mathrm{NaOH})$ concentrations (A) 2, (B) 3, (C) 4 and (D) $5 \mathrm{~mol}$.

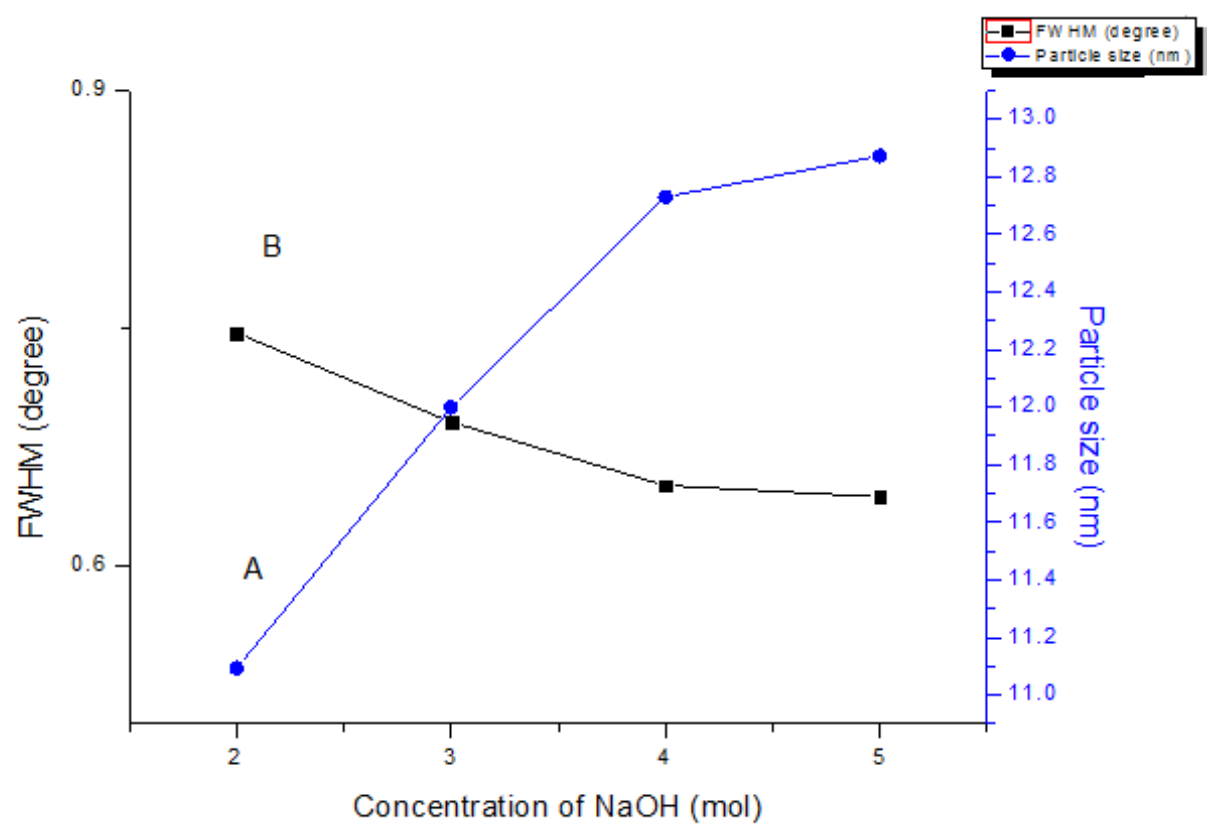

Fig. 6 The relation between (A) the changing in particle size and (B) FWHM of Synthesized $(\mathrm{ZnO})$ nanoparticles with increasing the $(\mathrm{NaOH})$ concentration.

Fig. 7 illustrates the (FT-IR) spectra of synthesized ( $\mathrm{ZnO})$ nanoparticles at temperature $30^{\circ} \mathrm{C}$, stirring time 2 hours and a variation of $(\mathrm{NaOH})$ concentration from (2-5) mol. The peak that appeared at wavenumber $571 \mathrm{~cm}^{-1}$ is related to the stretching vibrations of $\mathrm{Zn}-\mathrm{O}$. This 
peak is shifted to wavenumber $671 \mathrm{~cm}^{-1}$ with increasing the concentration of $\mathrm{NaOH}$ from 3 to $4 \mathrm{~mol}$ and appeared at the same position for the concentrations 3 and 5mol. The peak that appeared at wavenumber $3420 \mathrm{~cm}^{-1}$ indicates the presence of $\mathrm{OH}$ residue, probably due to atmosphere moisture. The best concentration of $\mathrm{NaOH}$ was found to be $4 \mathrm{~mol}$.

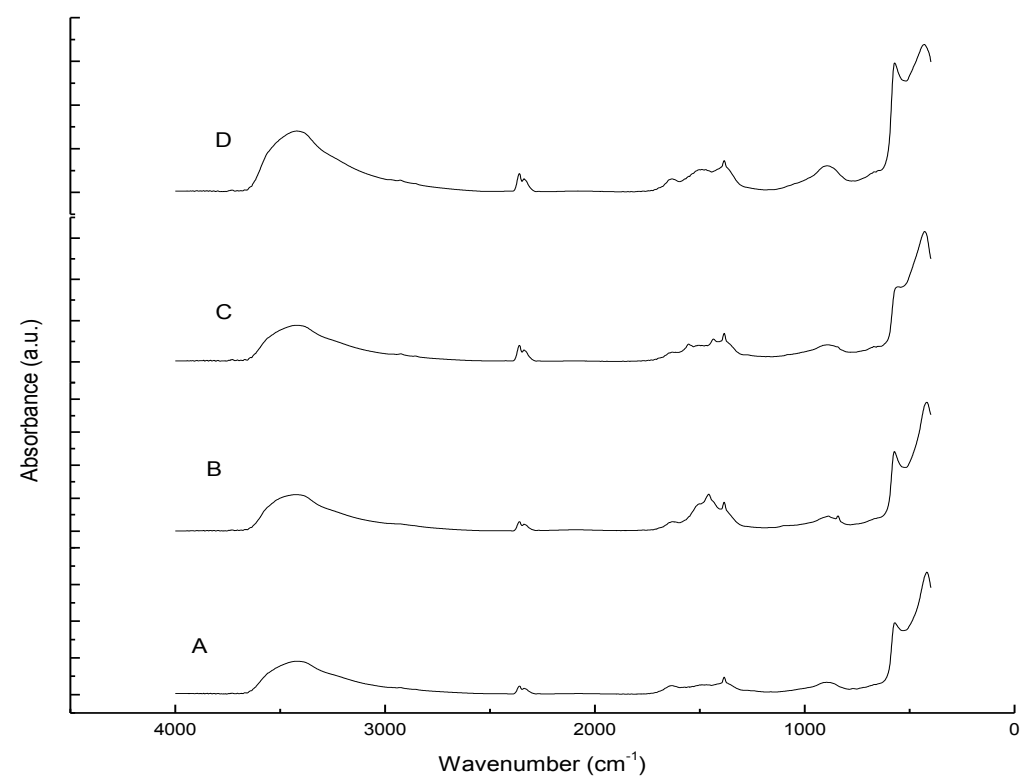

Fig. 7 FT-IR spectra of synthesized $(\mathrm{ZnO})$ nanoparticle at various concentration of $(\mathrm{NaOH})$ (A) 2, (B) 3, (C) 4 and (D) 5 at temp $30^{\circ} \mathrm{C}$ for time stirring $2 \mathrm{~h}$.

\subsubsection{Effect of stirring time}

In another trial, the effect of stirring time for the prepared sample was examined. $\mathrm{ZnO}$ nanoparticles were synthesized by keeping the temperature at $30^{\circ} \mathrm{C}$, the concentration of $\mathrm{NaOH}$ as $4 \mathrm{~mol}$ and the stirring time $2 \mathrm{~h}$ and $4 \mathrm{~h}$.Fig. 8 represented the (XRD) pattern of the synthesized $(\mathrm{ZnO})$ nanoparticle at the two values of stirring time. It was observed that the (FWHM) of (101) diffraction peak decreases by increasing the time of stirring. So, the calculated particle size of the synthesized $(\mathrm{ZnO})$ nanoparticles increased from $(14.6 \mathrm{~nm})$ to (16.9nm). 


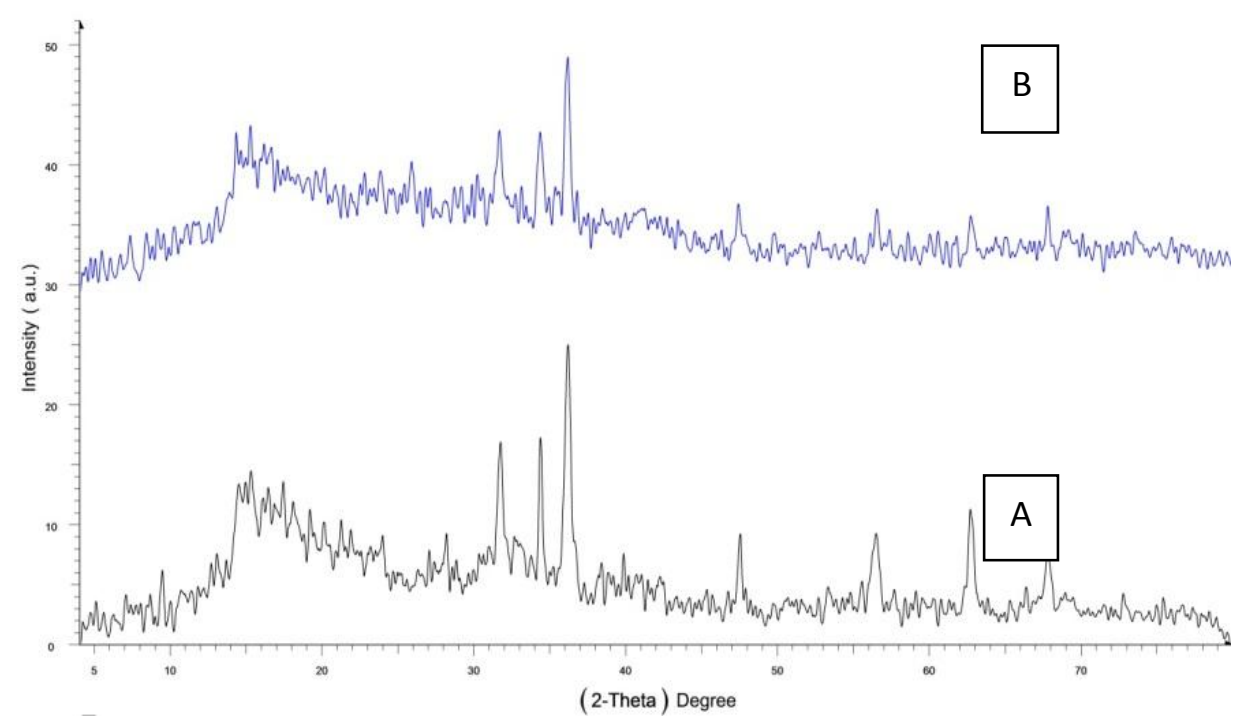

Fig. 8 XRD spectra of synthesized ( $\mathrm{ZnO}$ ) nanoparticles for stirring time (A) $2 \mathrm{~h}$ and (B) $4 \mathrm{~h}$ (concentration of $(\mathrm{NaOH}) 4 \mathrm{M}$ and temp $30^{\circ} \mathrm{C}$ ).

Fig. 9 shows the variation of (FT-IR) spectra of $(\mathrm{ZnO})$ nanoparticles at temperature $30^{\circ} \mathrm{c}$, concentration 4 of $(\mathrm{NaOH})$ and for stirring time 2 and 4 hours. The peak appeared at wavenumber $671 \mathrm{~cm}^{-1}$ shifted to $569 \mathrm{~cm}^{-1}$ when the time of stirring is increased from 2 to 4 hours. The best time of stirring of the synthesized $\mathrm{ZnO}$ nanoparticles was found to be $2 \mathrm{~h}$.

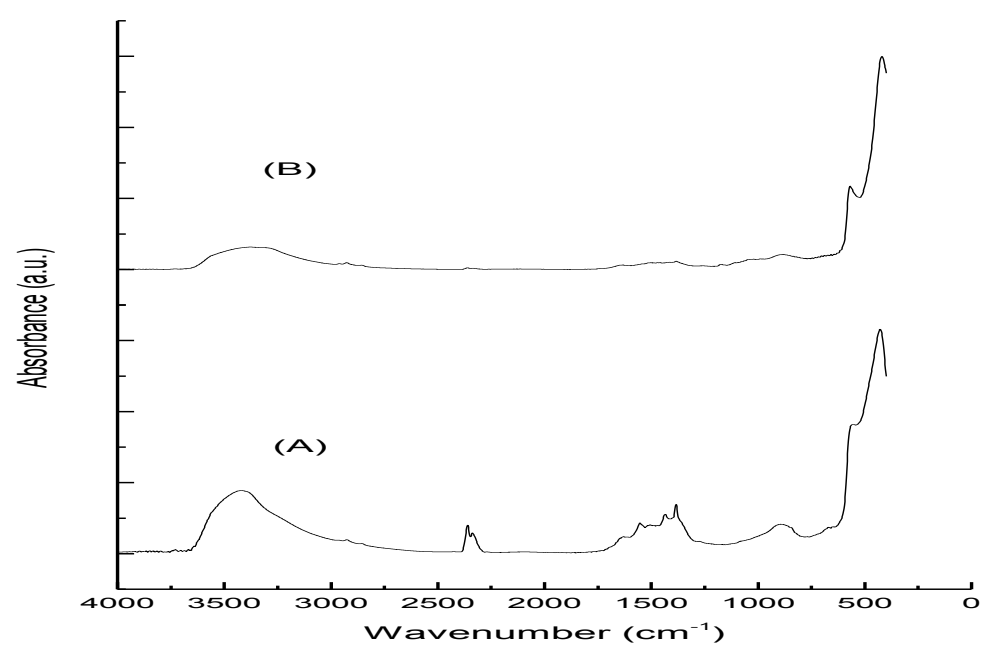

Fig. 9 FT-IR absorption spectra of synthesized $(\mathrm{ZnO})$ nanoparticles at temperature $30^{\circ} \mathrm{C}$, concentration 4 of $(\mathrm{NaOH})$ and for (A) 2 hours and (B) 4 hours.

\section{Conclusion}

Zinc Oxide nanoparticles have been prepared by Chemical precipitation method from Zinc nitrate and Sodium hydroxide. It was characterized by XRD, FT-IR spectrometer and TEM. The best synthesized $\mathrm{ZnO}$ nanoparticle is found to be at temp $30^{\circ} \mathrm{C}$, concentration of $\mathrm{NaOH} 4 \mathrm{~mol}$ and stirring time $2 \mathrm{~h}$. The XRD and TEM studies confirmed the nanostructures 
for the prepared $\mathrm{ZnO}$ nanoparticles. The calculated average size of the prepared $\mathrm{ZnO}$ is found to be $14.7 \mathrm{~nm}$ for peak absorbance wavelength. FT-IR absorption spectrum shows a series of absorption peaks from 500 to $4000 \mathrm{~cm}^{-1}$.

\section{Reference}

A. A. Keller, H Wang, D Zhou, H. S. Lenihan, G. Cherr, B. J. Cardinale, R. Miller and J. I. Zhaoxia, "Stability and Aggregation of Metal Oxide Nanoparticles in Natural Aqueous Matrices", Environ. Sci. Technol, Vol. 44 (2010).

A. Becheri, M. Durr, P. L. Nostro, P. Baglioni, J. Nanopart, "Synthesis and characterization of zinc oxide nanoparticles: application to textiles as UV-absorbers", Journal of Nanoparticle Research, Vol. 10 (2008) 679-689.

C. C. M. Ma, Y. J. Chen, H. C. Kuan,"Polystyrene nanocomposite materials Preparation, mechanical, electrical and thermal properties, and morphology", J. Appl. Polym.Sci., Vol. 100 (2006).

C. X. Xu, X. W. Sun, B. J. Chen, P. Shum, S. Li, X. Hu, "Nanostructural zinc oxide and its electrical and optical properties", J. Appl. Phys, Vol. 95 (2004).

D. Zaouk, Y. Zaatar, R. Asmar, and J. Jabbour, "Piezoelectric zinc oxide by electrostatic spray pyrolysis”, Microelectronics Journal, vol. 37 (2006) 1276-1279.

E. Solati, D. Dorranian. "Effect of temperature on the characteristics of $\mathrm{ZnO}$ nanoparticles produced by laser ablation in water", Bulletin of Materials Science, Vol.39 (2016) 16771684.

F. Q. He, Y. P. Zhao, "Growth of ZnO nanotetrapods with hexagonal crown" Appl. Phys., Vol. 88 (2006).

H. M. Ismail, "A thermoanalytic study of metal acetylacetonates", Journal of Analytical and Applied Pyrolysis, Vol. 21 (1991) 315-326.

J. J. Wu, S. C. Liu, "Low-Temperature Growth of Well-Aligned ZnONanorods by Chemical Vapor Deposition" Adv. Mater., Vol. 14 (2002).

K. Nejati, Z. Rezvani, R. Pakizevand. "Synthesis of ZnO Nanoparticles and Investigation of the Ionic Template Effect on Their Size and Shape", Int. Nano Lett, Vol. 1 (2011) 75-81.

M. Berber, V. Bulto, R. Kli $\beta$, H. Hahn, "Transparent nanocrystallineZnOfilms prepared by spin coating", Scr. Mater., Vol. 53 (2005).

M. Kahouli, A. Barhoumia, A. Bouzid, A. Al-Hajry, S. Guermazia, "Structural and optical properties of $\mathrm{ZnO}$ nanoparticles prepared by direct precipitation method", Science Direct, Vol. 85 (2015) 7-23.

M. Ristiae, S. Musiae, M. Ivanda, S. Popoviae, "Sol-gel synthesis and characterization of nanocrystalline ZnO powders" J. Alloys Compd, Vol. 397 (2005). 
N. Scarisoreanu, D. G. Matei, G. Dinescu, G. Epurescu, C. Ghica, L. C. Nistor, M. Dinescu, "Properties of $\mathrm{ZnO}$ thin films prepared by radio-frequency plasma beam assisted laser ablation", Appl. Surf. Sci., Vol. 247 (2005).

N. Takahashi, K. Kaiya, K. Omichi, T. Nakamura, S. Okamoto, H. Yamamoto, "Atmospheric pressure vapor-phase growth of $\mathrm{ZnO}$ using a chloridesource", J. Cryst. Growth, Vol. 209 (2000).

P. M. Aneesh, K. A. Vanaja, M. K. Jayaraj. "Synthesis of $\mathrm{ZnO}$ nanoparticles by hydrothermal method”, Nanophotonic Materials (2007).

R. Zhang, L. L. Kerr, "A simple method for systematically controlling ZnO crystal size and growth orientation", J. Solid State Chem., Vol. 180 (2007) 988-994.

S. Baskoutas , P. Giabouranis , S. N. Yannopoulos , V. Dracopoulos , L. Toth , A. Chrissanthopoulos , N. Bouropoulos, "Preparation of $\mathrm{ZnO}$ nanoparticles by thermal decomposition of zinc alginate", Thin Solid Films, Vol. 515 (2007) 8461-8464.

S. C. Ko, Y. C. Kim, S. S. Lee, S. H. Choi, and S. R. Kim, "Micromachined piezoelectric membrane acoustic device", Sensors and Actuators, vol. 103 (2003) 130-134.

S. D. Skapin, G. Drazic, Z. C. Orel, "Microstructure of nanoscale zinc oxide crystallites", Mater. Lett., Vol. 61 (2007).

S. Radhika, J.Thomas, " Solar light driven photocatalytic degradation of organic pollutants using $\mathrm{ZnO}$ nanorods coupled with photosensitive molecules", Journal of Environmental Chemical Engineering, Vol. 5 (2017).

S. Talam, S. RaoKarumuri and N. Gunnam, "Synthesis, Characterization, and Spectroscopic Properties of $\mathrm{ZnO}$ Nanoparticles" (2012).

T. Paul1, P. P Saikia2 and M. K Baruah2, "X-ray and infrared studies of $\mathrm{ZnO}$ and transition metal-doped $\mathrm{ZnO}$ nanomaterials", International Journal of Latest Research in Science and Technology, Vol. 4 (2015) 62-64.

Y. F. Chen, D. M. Bagnall, H. J. Koh, K. T. Park, K. Hiraga, Z. Q. Zhu, T. Yao, "Plasma assisted molecular beam epitaxy of $\mathrm{ZnO}$ on $c$-plane sapphire: Growth and characterization", J. Appl. Phys., Vol. 84 (1998).

Y. Gyu-Chul, W. Chunrui and P. IL Won "ZnOnanorods: synthesis, characterization and applications", Semicond. Sci. Technol,Vol. 20 (2005).

Z. L. Wang, "Zinc oxide nanostructures: growth, properties and applications", Journal of physics: condensed matter, Vol.16 (2004) 829-858.

Z. M. Khoshhesab, M. Sarfaraz, and M. A. Asadabad, "Preparation of ZnO nanostructures by chemical precipitation method", Synthesis and Reactivity in Inorganic, Metal-Organic and Nano-Metal Chemistry, Vol. 41 (2011) 814-819.

Z. Qiuxiang, Y. Ke, B. Wei, W. Qingyan, X. Feng, Z. Ziqiang, D. Ning, S. Yan, "Synthesis, optical and field emission properties of three different $\mathrm{ZnO}$ nanostructures", Materials Letters, Vol. 61 (2007). 


\section{دراسات طيفية لأكسيد الزتك النانومتري}

\section{نيفين محمود حامد ، عايدة البيلي ، سوسن سيد حامد ، سميرة عبد المنجي قسم الفيزياء ـ كلية البنات للأداب و العلوم و التربية - جامعة عين شمس}

تم تحضير جزيئات أكسيد الزنك النانونيه بو اسطة طريقة الترسيب الكيميائي من نتر ات الزنك و هيدروكسيد الصوديوم. تم در اسة افضل الظروف المؤثره علي حجم الجزيئات للعينات المحضرة كدرجة الحر ارة وتركيز الصوديوم هيدروكسيد وزمن التقليب .و اختبرت العينات المحضرة بو اسطة حيود الأشعة السينيةXRD ، مطياف الاشعة تحت الحمر اء بتحوير فورير FT-IR، المجهر الالكتروني TEM. ووجد ان افضل الظروف للتحضير هي درجة الحرارة 30 درجة وتركيز هيدروكسيد الصوديوم 4 مول وزمن التقليب ساعتان ـ أما حجم الجزيئات المحضرة لاكسيد الزنكالنانومثرية فكان متوسط القيم المحسوبة من معادلة Scherrer formula بأستخدام الاشعة السينية 14,7 نانو متر . 